\title{
Keep it local and fish-friendly: Social acceptance of hydropower projects in Switzerland
}

\author{
Andrea Tabi, Rolf Wüstenhagen* \\ University of St.Gallen, Institute for Economy and the Environment (IWÖ-HSG), Good Energies Chair for Management of Renewable Energies, \\ Tigerbergstrasse 2, CH-9000 St. Gallen, Switzerland
}

\section{A R T I C L E I N F O}

\section{Keywords:}

Social acceptance

Environmental justice

Discrete choice experiment

Choice-based conjoint analysis

Hierarchical Bayes estimation

Hydropower

\begin{abstract}
A B S T R A C T
Hydropower is the largest source of renewable electricity in the world, but despite being a mature and clean energy technology it has also been the subject of ecological and social conflict. Literature suggests that the social acceptance of renewable energy can be increased by respecting procedural justice (fair, participatory planning processes) and distributional justice (fairly allocating costs and benefits). However, empirical evidence about how justice considerations are related to the expansion of hydropower is scarce, pre-existing studies being mostly qualitative in nature. We contribute to filling the gap in the current literature by describing in this paper how choice experiments with 1004 Swiss residents were undertaken to explore the influence of procedural and distributional justice on acceptance, relative to other attributes of hydropower projects. We find that while considerations about justice do play a role in decisions to accept, respondents in Switzerland care most about ecological impacts, and secondly about local ownership.
\end{abstract}

\section{Introduction}

\subsection{Social acceptance of renewable energies}

As the world is slowly but surely making progress in transitioning from non-renewable to renewable energy sources, there has been a surge in research on social acceptance (Fig. 1). Data from Scopus indicates that in the last decade alone 350 articles with the keyword "social acceptance" have been published in energy and environmental science journals, with an exponential increase occurring towards the end of this period. According to ScienceDirect, Renewable and Sustainable Energy Reviews was one of the two most popular publications for social acceptance research, as measured by the total number of articles using this keyword in 2014. ${ }^{1}$ An increasing policy focus on the deployment of renewable energies has contributed to the interest in this topic. With the increasing maturity of renewable energy technologies, the challenges of the energy transition are shifting towards obtaining a "social license for clean energy deployment".

A widespread definition of social acceptance of renewable energy is Wüstenhagen et al.'s [66] conceptual framework suggesting that social acceptance is a three-dimensional construct, consisting of sociopolitical, community and market acceptance.
The objective of this paper is to (a) review the recent literature on social acceptance of renewable energies, with a particular focus on (b) social acceptance of hydropower, and (c) the role of distributional and procedural justice in explaining social acceptance. Furthermore, we build on the results of the literature review to develop a conceptual framework of social acceptance of hydropower, which we then test in a large-scale empirical survey.

\subsection{Social acceptance of hydropower}

In light of its significant potential for contributing to the global energy transition and its mixed record in terms of social acceptance, research on hydropower is surprisingly absent from the recent academic literature. In his comprehensive review of hydropower, Sternberg [55] states that social acceptance is one of the key topics to be addressed, but leaves it to further research to close the gap. From all the articles published in 2014 that included the keywords "social acceptance" in the two most important energy journals that address the issue (Renewable and Sustainable Energy Reviews, and Energy Policy) wind energy is currently the most frequently-addressed source of energy, followed by biomass (including biogas and biofuels), solar energy, Carbon Capture and Storage (CCS) and nuclear power.

\footnotetext{
* Corresponding author.

E-mail address: rolf.wuestenhagen@unisg.ch (R. Wüstenhagen).

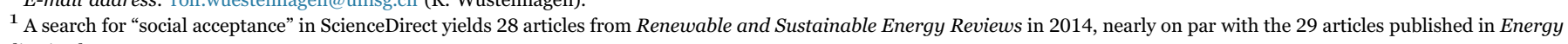
Policy in the same year.

${ }^{2}$ http://www.cleanenergyministerial.org/Events/CEM6/Roundtable/SocialLicenseCleanEnergy.
} 


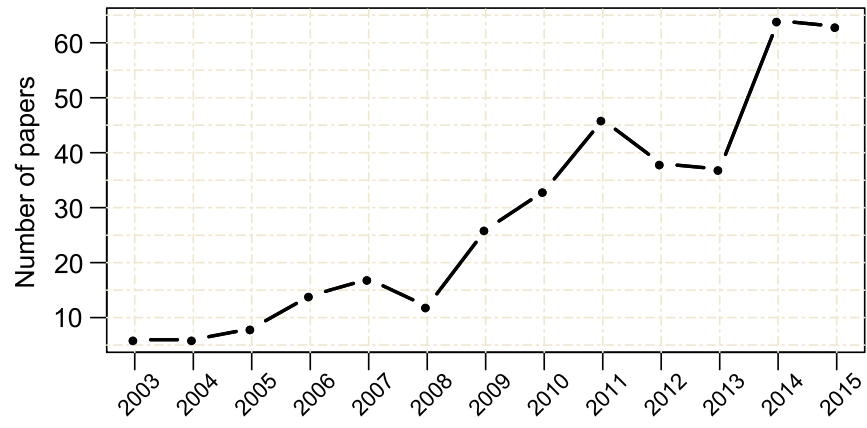

Fig. 1. Number of articles published per year with keyword "social acceptance" in energy and environmental science journals (2003-2015)

Source: Scopus

Hydropower and shale gas, both arguably providing rich empirical contexts for studying social acceptance, appear to be relatively underresearched topics.

Two approaches to empirically investigating social acceptance of hydropower can be identified in the academic literature. The first stream of research addresses the social acceptance of hydropower using a case study approach, often in remote areas or developing countries $([3,21,26,27,28,37,52,51,67])$. These papers provide rich evidence about the challenges involved in implementing hydropower in economically underdeveloped areas. Similarly to the findings of case studies about the social acceptance of other energy sources (e.g. [16]), these studies tend to conclude - sometimes based on qualitative empirical evidence, sometimes arguing from a normative perspective that greater participation of local communities in hydropower projects can be positively correlated with social acceptance.

A second research direction concerns environmental valuation studies [56] which are designed to quantify the (external) costs and benefits of hydropower (or other uses of water resources) and their associated impacts on the local environment $[15,4,63]$. What can be learned from this stream of literature is that respondents value an intact environment to varying degrees, and that negative impacts on the environment can to some extent be compensated for in monetary form. However, the empirical validity of findings from the environmental valuation literature has been the subject of extended debate $[12,42]$. While some researchers critique the experimental methods used by environmental economists for employing decision situations that are remote from the real life experiences of respondents, there has arguably been some progress in increasing situational realism [5]. One particularly promising innovation is the introduction of choice experiments $[11,17,23,25,59]$ which obtain a richer account of respondent preferences than more direct methods soliciting willingness-to-pay for environmental resources.

\subsection{Environmental justice and social acceptance}

One key learning from a decade of social acceptance research is that 'monetary-compensation-for-environmental-damage' approaches that underlie traditional contingent valuation studies are overly simplistic. Instead, it has been shown that social acceptance of energy projects is closely interlinked with environmental justice and its two main dimensions, procedural justice and distributional justice $[16,20,38]$.

\subsubsection{Procedural justice}

Procedural justice refers to the "how" of environmental decisionmaking. Research in social psychology points out that outcomes are more likely to be accepted if the processes that lead to these outcomes are perceived to be fair - an issue that has also a long-standing tradition in legal research [57]. Lind and Tyler [31] identified a number of principles that constitute procedural justice. Processes, they argue, should for example be consistent, accurate, and representative [62].
Procedural justice is closely linked to trust [20]. A key driver of perceived procedural justice, and hence potentially social acceptance, is participatory planning and decision-making [32,35,43,44,66]. Participation can also take the form of financial participation in a renewable energy project, a factor that has been shown to not only foster social acceptance [39] but also physical well-being of local inhabitants in the case of wind turbines [46]. Carefully designed institutional frameworks can increase perceived procedural justice, which is the idea behind public participation in environmental impact assessments [45].

While it is common sense that a high degree of procedural justice is a desirable objective for renewable energy project developers, implementing the principles of procedural justice in reality requires addressing trade-offs. Non-trivial questions include delineating the boundary of stakeholders to be involved in the process [40], as well as how early and to what extent participation should be organized to be fair and manageable at the same time [62].

\subsubsection{Distributional justice}

In contrast to procedural justice, distributional justice deals with the "what" of environmental decision-making. People are more likely to accept an outcome if the costs and benefits are fairly allocated. When it comes to renewable energy projects, the costs can include monetary costs, but also non-monetary factors such as negative impacts on flora, fauna and landscape. Similarly, the benefits can be either tangible (e.g. revenues from power generation) or intangible (e.g. contribution to local, low-carbon energy supply). Fairness considerations with regard to the distribution of costs and benefits can apply to the relationship between renewable energy project developers and an affected local community, but can also play a role among members of the community (e.g. distribution of royalties between landowner and other inhabitants; $[16,62])$.

Similar to procedural justice, a set of principles can be identified that determine distributional justice. The three most prominent principles are equity, equality and need [54,62]. According to the equity principle, outcomes should be proportional to inputs provided by different project stakeholders. The equality principle suggests that everyone should have an equal share in an outcome, while the needs principle suggests that those in need of the benefits should get a larger share. Applying these principles to distributional justice in the context of renewable energy projects is not a straightforward proposition, as different stakeholders of the project may have different views on what is fair, and even an individual may prefer different principles for the distribution of different types of costs and benefits [22], to the extent that some observers conclude that distributional justice is "in the eye of the beholder" [60]. When it comes to hydropower, a traditional instrument to support distributional justice is the Swiss water resource tax (Wasserzins), which is a mandatory benefit sharing scheme between hydropower operators and the municipalities and cantons whose waterways they use, and has first been introduced in 1918 [34].

While it appears plausible that there is some positive correlation between environmental justice and social acceptance [16], project developers and policymakers need to know to what extent this is the case if they are to conduct effective planning: greater participation and benefit-sharing may positively affect social acceptance, but they also come at a cost.

\subsection{Research context: swiss hydropower}

This paper describes research that was designed to appraise the influence of procedural and distributional justice on social acceptance relative to ecological impacts and other features of a hydropower project. In terms of our methodological approach, we used choice experiments because they allowed us to test, simultaneously and in a realistic setting, how various attributes of a hydropower project influence the decision to accept. We conducted our research in 


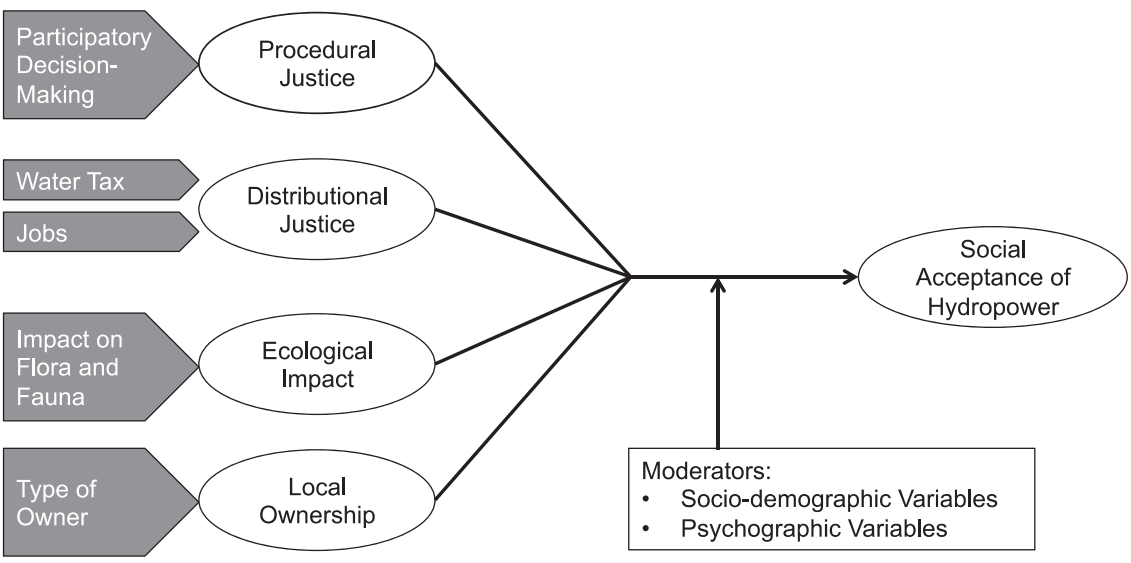

Fig. 2. Conceptual framework for investigating social acceptance of hydropower.

Switzerland, which provides a particularly relevant context for a number of reasons. First, hydropower has traditionally played an important role in the Swiss energy mix, accounting for more than half of the country's power generation $(56.4 \%, 39.3$ TWh in 2014; [5]). Second, expanding the role played by hydropower is one of the key pillars of the government's ambitious energy strategy 2050 (www. energiestrategie2050.ch). Finally, the trade-off between increasing the amount of electricity obtained from hydropower and other environmental policy objectives (e.g. protecting and rehabilitating water bodies, conserving ecosystems and biodiversity), combined with Switzerland's high population density, offers a promising setting for investigating social acceptance.

The key research question we address is: "What is the influence of procedural justice and distributional justice on social acceptance, compared to other attributes of a hydropower project?" - Fig. 2 illustrates the conceptual framework that underlies our research. Individual variables are described in Section 2.

The rest of this article is organized as follows: Section 2 describes data and methods; Section 3 presents the empirical findings of our choice experiment; Section 4 discusses the most important findings in light of pre-existing literature and Section 5 concludes the paper, including a discussion of limitations and further research.

\section{Data and methods}

\subsection{Sample}

Data were collected through a nationwide representative survey of 1004 Swiss citizens $^{3}$ between October 29 and November 6, 2014. The core of the questionnaire was a choice experiment on social acceptance of hypothetical hydropower projects. Furthermore, we surveyed people's attitudes to climate change and key socio-demographic variables. We used Sawtooth Software to design the choice experiment. To ensure the participation of a representative sample we relied on a household panel operated by a professional market research agency using quota sampling with computer-assisted web interviews (CAWI). The overall drop-out rate was 14.5\%; a total of 1004 respondents completed the online questionnaire. The sample was representative of the Swiss population in terms of gender, age and household income (see Table 1). The survey was translated into German and French. The Italian and Rhaeto-Romanic speaking parts of Switzerland were excluded from the sampling pool, as they represent only $6.5 \%$ and $0.5 \%$ of the total population, respectively [50].

\footnotetext{
${ }^{3}$ This sample is larger than previous studies using choice experiments to investigate social acceptance, for example Caporale and de Lucia [11] (N=375), [25] (N=892) and [59] $(\mathrm{N}=450)$.
}

Table 1

Socio-demographic characteristics of respondents compared to the Swiss population. (Source: [6]).

\begin{tabular}{|c|c|c|c|}
\hline & $\begin{array}{l}\text { Swiss } \\
\text { population }\end{array}$ & $\begin{array}{l}\text { Sample } \\
(N=1004)\end{array}$ & Deviation \\
\hline \multicolumn{4}{|l|}{ Gender } \\
\hline Male & $49 \%$ & $49 \%$ & 0 \\
\hline Female & $51 \%$ & $51 \%$ & 0 \\
\hline \multicolumn{4}{|l|}{ Age } \\
\hline 19-29 years old & $22 \%$ & $22 \%$ & 0 \\
\hline 30-44 years old & $25 \%$ & $24 \%$ & $-1 \%$ \\
\hline $45-59$ years old & $26 \%$ & $27 \%$ & $+1 \%$ \\
\hline $60+$ years old & $27 \%$ & $27 \%$ & 0 \\
\hline \multicolumn{4}{|c|}{ Monthly Household Income } \\
\hline up to $6^{\prime} 000 \mathrm{CHF}$ & $30 \%$ & $26 \%$ & $-4 \%$ \\
\hline 6'001 to 9'000 CHF & $25 \%$ & $30 \%$ & $+5 \%$ \\
\hline 9'001 to $12^{\prime} 000 \mathrm{CHF}$ & $19 \%$ & $22 \%$ & $+3 \%$ \\
\hline$>12 ' 000 \mathrm{CHF}$ & $27 \%$ & $21 \%$ & $-6 \%$ \\
\hline \multicolumn{4}{|l|}{ Region } \\
\hline $\begin{array}{l}\text { Western Switzerland } \\
\text { (French-speaking } \\
\text { part) }\end{array}$ & $25 \%$ & $25 \%$ & - \\
\hline Alps and Prealps & $24 \%$ & $24 \%$ & - \\
\hline Swiss Plateau West & $22 \%$ & $22 \%$ & - \\
\hline Swiss Plateau East & $29 \%$ & $29 \%$ & - \\
\hline
\end{tabular}

\subsection{Survey design}

The first part of the survey included questions to evaluate respondents' pre-existing knowledge about the impact of hydropower, their relationship with water courses in their close environment and their opinions about expanding the use of hydropower. This section was followed by the choice experiment. The attributes and levels used in the choice experiment are presented in Table 2. These are based on a review of the social acceptance literature and expert interviews, including some with natural scientists who examine the ecological impacts of hydropower production. The exact wording of the choice task was the following: "The Swiss Federal Council wants to expand hydropower production according to the Energy Strategy 2050. Imagine that you are to choose between three hydropower projects (all of which are run-of-the-river plants with a capacity of $10 \mathrm{MW}$ ) in your canton. The projects differ in the following respects." The first attribute, ecological impact, describes the hypothetical change in landscape and natural biodiversity that would be caused by a hydropower project. Hydropower has numerous adverse ecological impacts on the aquatic environment. Dams create barriers across rivers, leading to habitat fragmentation, which prevents aquatic animals (e.g. fish and benthic invertebrates such as snails, crustaceans and insect larvae) 
Table 2

Attributes and levels of hydropower projects presented in the choice experiment.

\begin{tabular}{|c|c|c|}
\hline Attributes & Description & Levels \\
\hline $\begin{array}{c}\text { Ecological } \\
\text { impact }\end{array}$ & $\begin{array}{l}\text { Impacts on aquatic and } \\
\text { riparian ecosystem and the } \\
\text { landscape }\end{array}$ & $\begin{array}{l}\text { Almost none (AN), small } \\
(\mathrm{S}) \text {, medium }(\mathrm{M}) \text {, large (L) }\end{array}$ \\
\hline $\begin{array}{l}\text { Public } \\
\text { participation }\end{array}$ & $\begin{array}{l}\text { Public involvement in the } \\
\text { decision and planning process } \\
\text { for hydropower plant }\end{array}$ & $\begin{array}{l}\text { Information brochures } \\
\text { (IB), public hearing }(\mathrm{pH}) \text {, } \\
\text { participative planning } \\
\text { process (PPP), } \\
\text { referendum (R) }\end{array}$ \\
\hline Employment & $\begin{array}{l}\text { Number of jobs created } \\
\text { directly or indirectly by the } \\
\text { construction of the } \\
\text { hydroelectric power plant in } \\
\text { respondents' canton }\end{array}$ & $10,20,30,40$ jobs \\
\hline $\begin{array}{l}\text { Income from } \\
\text { water tax }\end{array}$ & $\begin{array}{l}\text { The annual dividend paid to } \\
\text { communities and/or the } \\
\text { canton - to be used for public } \\
\text { purposes in respondents' } \\
\text { community or canton }\end{array}$ & $\begin{array}{l}0.75,1.0,1.25,1.5 \text { million } \\
\text { CHF/year }\end{array}$ \\
\hline $\begin{array}{l}\text { Owner of the } \\
\text { plant }\end{array}$ & $\begin{array}{l}\text { The owner who operates the } \\
\text { hydropower plant }\end{array}$ & $\begin{array}{l}\text { Local utility (LU), } \\
\text { cantonal utility (CU), } \\
\text { private domestic company } \\
\text { (PDC), German company } \\
\text { (GC) }\end{array}$ \\
\hline
\end{tabular}

from migrating upstream. Migratory fish such as salmon and nase are obstructed from reaching their spawning areas. Furthermore, artificial barriers also modify sediment regimes, preventing downstream movement, which causes alterations to bedload transport and substrate composition. Hydropeaking affects most of the abiotic and biotic components of ecosystems, which are connected through a variety of interactions. Artificial fluctuations in flow rates modify natural flow regimes, contributing to alterations of the riverbed, detrimentally affecting habitats for plants and animals through decreasing water levels, and also changing water temperature [64]. These effects lead to long-term reductions in the abundance and biomass of sensitive species and a shift in species composition towards more resistant species [9]. Since the effects of hydropower generation on ecosystems are too complex to be easily understood by lay respondents, our survey presented aggregate impacts in a simplified way.

Other attributes were designed to capture respondents' preferences for a variety of procedural and distributive justice scenarios. Procedural justice was operationalized as "public participation" in project planning; i.e. the degree of public involvement in the planning process, which ranged from "information brochure" (representing a rather limited one-way communication from the project developer to affected residents) to "referendum" (representing the highest degree of participation, including a veto right for residents). As for the distribution of economic and social gains, two obvious ways in which hydropower can benefit local populations are through job creation and tax revenue. Job creation is an important consideration in policy makers' decisions about whether to support renewable energy [29] and has been shown to be positively correlated to social acceptance of hydropower in former research [25]. We therefore included the attribute employment, using a variety of realistic estimates of the number of local (i.e. in the respondent's canton) jobs that would be directly or indirectly created by a $10 \mathrm{MW}$ power plant. As concerns tax income, Swiss legislation obliges operators of hydropower plants to pay a tax to the canton and/or local community known as the water tax ("Wasserzins"; [19]). Accordingly, we included this monetary attribute into the choice experiment. To provide a context for the attribute levels employed in the choice experiment, the average water tax rate that is currently paid is around $1 \mathrm{Rp} . / \mathrm{kWh}$. The survey specified that the amount of water tax payable to the canton and/or municipality would be ranging from 0.75 to 1.5 Mio CHF per year, which corresponds to $1.25-2.50 \mathrm{Rp} . / \mathrm{kWh}$, assuming $10 \mathrm{MW}$ installed capacity and 6000 full load hours.

In addition to these direct measures of distributional justice, we were interested in finding out whether local ownership would positively influence the social acceptance of hydropower. Previous research into green electricity has shown that some consumers have a preference for local power generation [58], and the emergence of community financing schemes and local renewable energy cooperatives has occurred in a variety of countries, including Japan [39], Germany [61] and the Netherlands [8]. The ownership attribute contrasted local with non-local companies using four levels, including a foreign investor (specified as being a German company, which is a reasonably realistic option for the Swiss market given the two countries' cultural and geographical proximity).

\subsection{Data analysis}

Discrete choice experiments (DCE) are a commonly used research method for measuring stated preferences and have been applied in many fields (e.g. $[17,48,36,24,14,25,65])$. They have several advantages over traditional ranking or rating methods: respondents are facing a realistic decision situation, and indirect preference measurement allows the researcher to minimize biases that occur when respondents are directly asked to state their preferences [68]. The theoretical background of DCE is derived from classic random utility theory, which assumes that individuals seek to maximize their utility [33]. DCE are widely applied in new product development, because in the context of new products it is impossible to observe actual purchasing behavior or measure preferences through revealed preference methods [13]. Correspondingly, use of the method has risen in popularity in many areas of social science, including environmental economics. In discrete choice experiments, respondents are presented with a number of hypothetical products (or other choice objects) that mirror real choice situations and are asked to choose the one that best matches their preferences. The choice task is repeated with varying combinations of attribute levels [48]. Respondents' preferences for the attributes of the choice object are then implicitly derived from the choices that they make. This method facilitates understanding of how product attributes and their levels affect demand for certain products and also permits investigation into the interaction that exists between attributes. This study is based on a choice-based conjoint (CBC) analysis, the most frequently used conjoint-based method. In the choice experiment we employed a balanced overlap option, which represents a middle position between random and complete enumeration strategies (n.b. no duplication occurs within the same task) [49].

We used hierarchical Bayes (HB) estimation to analyze the results of the choice experiment. HB estimation is a combination of two methods: (1) The Bayesian method; and, (2) a hierarchical model (also called a mixed effects model). For analysis of the conjoint data we employed a mixed logit model with random intercept for the estimation of the betas:

$\operatorname{Pr}(i)_{h}=\frac{\exp \left[x_{i}{ }^{\prime} \beta_{h}\right]}{\sum_{j} \exp \left[x_{j}{ }^{\prime} \beta_{h}\right]}$

where $\operatorname{Pr}(\mathrm{i})_{\mathrm{h}}$ denotes the probability of respondent $\mathrm{h}$ to choose the ith alternative of the choice object, $\mathrm{x}$ is a vector of attribute levels that describes the choice object and $\beta_{\mathrm{h}}$ is a vector of regression coefficients that represents the part-worth utility of each attribute level. Since we are interested in the heterogeneity of the responses, we define $\beta_{\mathrm{h}}$ as a random intercept term:

$\beta_{h}=\Gamma z_{h}+\xi_{h} \xi_{h} \sim M V N\left(0, V_{\beta}\right)$

where $\Gamma$ is a matrix of regression coefficients which affects the location of the distribution of heterogeneity given that $\mathrm{z}_{\mathrm{h}}$ and $\xi_{h}$ are error terms that are assumed to follow a multivariate normal distribution pattern [2]. Accordingly, the hierarchical form of the model relates to the 
interpretation of the mixed effects structure of the model; i.e. estimation of part-worth utilities occurs at two levels: within each respondent and across all respondents. The parameters are estimated using an iterative process (20'000 draws) where the vector of means, the covariance matrix and a vector of betas are re-estimated for each respondent. The advantage of the Bayesian approach over the classical procedure is its ease of implementation - due to the use of Gibbssampling and the Metropolis-Hastings algorithm it does not involve a maximization processes [53].

The reason that we use the part-worth utility term stems from the alternative interpretation of logit models, which incorporate a latent variable that cannot be observed directly and depend on $\mathrm{x}_{\mathrm{i}}$ :

$y^{*}=x_{i}^{\prime} \beta+u_{i}, u_{i} \mid x_{i} \sim N\left(0, \sigma^{2}\right)$

$E\left(u_{i}\right)=0$

the latent variable $y^{*}$ is interpreted as the utility difference between the choice $y_{i}=1$, or 0 . Only choice $y_{i}$ can be observed:

$y_{i}=\left\{\begin{array}{lll}1 & \text { if } & y_{i}^{*}>0 \\ 0 & \text { if } & y_{i}^{*} \leq 0\end{array}\right.$

so, if the latent variable is positive, this indicates positive utility regarding the subject under examination. This decision rule provides the basis for Random utility theory (RUT). Following this, the regression coefficients from the HB estimation can be used for describing respondent's utilities for certain attribute levels in the conjoint analysis.

The goodness of fit of the HB model is indicated by the root likelihood (RLH) that is calculated for each respondent. RLH is the geometric mean of the predicted probabilities and is calculated by taking the $\mathrm{nth}$ root of the likelihood where $\mathrm{n}$ is the total number of choices made by all respondents in all tasks. The best possible (theoretical) value is 1.0 while the worst possible value is the reciprocal of the number of choices available in the average task; i.e., the expected RLH value for a chance model is $1 / k$, where $k$ is the number of alternatives in each choice task. For our model it is $1 / 4=0.25$ (Sawtooth Software [49]).

In order to investigate which factors moderate preferences, a stepwise linear regression analysis was performed using the most preferred attribute levels as dependent variables and psychographic and socio-demographic factors as explanatory variables (as detailed in Appendix A). We used the 'stepAIC' function to select the most parsimonious model based on the AIC (Akaike information criterion) performing a backward selection process. All the variables (except for dichotomous variables) were mean-centered in the analysis. Sawtooth 8.3.10 and R software [47] were used in the analysis.

\section{Results}

\subsection{Attribute importances and part-worth utilities}

The average RLH of the HB model is 0.7861 (std. dev.=0.1106), which indicates a very good model fit. Both the raw and the rescaled part-worth utilities are shown in Table 4. The rescaled utilities allow for a better comparison across attributes mitigating the scale effect.

Table 3

Descriptive statistics of attribute importances.

\begin{tabular}{lllll}
\hline & Mean & Std. Dev. & Minimum & Maximum \\
\hline Ecological impact & 41.51 & 19.12 & 3.21 & 85.61 \\
Water tax & 7.55 & 5.22 & 0.66 & 43.01 \\
Ownership & 30.59 & 16.35 & 0.49 & 74.81 \\
Employment & 10.57 & 6.72 & 0.77 & 54.90 \\
Public participation & 9.76 & 6.26 & 0.79 & 58.81 \\
Total & 100.00 & - & - & - \\
\hline
\end{tabular}

Table 4

Results of the Hierarchical Bayes model estimation. In the first column the average partworth utilities are shown (standard deviation are in parentheses) and in the second column the rescaled utilities are depicted for a better comparison across attribute levels. Positive values indicate positive preferences for the given attribute level.

\begin{tabular}{|c|c|c|}
\hline & $\begin{array}{l}\text { Average utilities } \\
\text { (raw) }\end{array}$ & $\begin{array}{l}\text { Average utilities (zero- } \\
\text { centered diffs) }\end{array}$ \\
\hline \multicolumn{3}{|l|}{ Ecological impacts } \\
\hline Almost none & $3.64(3.51)$ & $68.14(64.94)$ \\
\hline Small & $2.37(1.76)$ & $46.32(33.23)$ \\
\hline Medium & $-0.39(1.07)$ & $-5.29(23.98)$ \\
\hline Large & $-5.63(4.29)$ & $-109.17(77.44)$ \\
\hline \multicolumn{3}{|l|}{ Water rate } \\
\hline 0.75 million $\mathrm{CHF} /$ year & $-0.57(0.74)$ & $-13.19(19.13)$ \\
\hline 1.0 million $\mathrm{CHF} /$ year & $0.04(0.49)$ & $1.04(12.81)$ \\
\hline 1.25 million $\mathrm{CHF} /$ year & $0.14(0.55)$ & $3.27(13.66)$ \\
\hline 1.5 million $\mathrm{CHF} /$ year & $0.38(0.63)$ & $8.87(16.33)$ \\
\hline \multicolumn{3}{|l|}{ Ownership } \\
\hline Cantonal utility & $1.98(1.60)$ & $47.45(39.06)$ \\
\hline Local utility & $2.00(1.58)$ & $38.97(34.52)$ \\
\hline Private domestic company & $0.07(1.12)$ & $1.21(27.28)$ \\
\hline German company & $-4.07(2.67)$ & $-87.63(61.04)$ \\
\hline \multicolumn{3}{|l|}{ Employment } \\
\hline 10 jobs & $-1.00(0.96)$ & $-21.71(23.06)$ \\
\hline 20 jobs & $-0.15(0.56)$ & $-2.86(15.42)$ \\
\hline 30 jobs & $0.36(0.51)$ & $7.53(13.20)$ \\
\hline 40 jobs & $0.79(0.93)$ & $17.05(22.82)$ \\
\hline \multicolumn{3}{|l|}{ Public participation } \\
\hline Information brochures & $-0.60(0.77)$ & $-13.17(20.39)$ \\
\hline Public hearing & $-0.11(0.73)$ & $-0.88(19.68)$ \\
\hline $\begin{array}{l}\text { Participative planning } \\
\text { process }\end{array}$ & $0.58(0.80)$ & $11.68(20.69)$ \\
\hline Referendum & $0.13(0.89)$ & $2.36(23.91)$ \\
\hline RLH value & $0.7861(0.1106)$ & \\
\hline
\end{tabular}

Attribute importance is expressed as a percentage, which is calculated from the absolute distance between the part worth utilities (regression coefficients) of the most and the least preferred level of a given attribute, divided by the sum of those distances across all attributes (Table 3). The importances of all attributes included in the choice experiment add up to $100 \%$. Fig. 3 depicts the distribution of the attribute levels (random intercepts) across the sample. Ecological impact and ownership attributes display a relatively high level of heterogeneity whereas the other attributes show less variation.

The ecological impacts of a future hydropower project are by far the most important attribute (41.51\%). This finding is in line with the high level of public awareness about the potentially negative consequences of currently planned projects in Switzerland. ${ }^{4}$ It seems that low ecological impact is a prerequisite for social acceptance of further expansion of hydropower. The second most important attribute is (local) ownership: respondents stated that they would strongly prefer a local or regional owner over a private domestic or foreign company. The relative importance of this attribute is $30.59 \%$ on average, but it has a similarly wide range as for ecological impacts. This suggests that, for the majority of respondents, ecological considerations and/or the type of owner are key factors that determine social acceptance of a hydropower project.

We found support for the two attributes that we included as direct measures of distributional justice, although their importance was lower. The employment attribute is the third-most important attribute overall, but at $10.57 \%$ is considered clearly less important than ecological impacts and local ownership. The direction of the effect is

\footnotetext{
${ }^{4}$ One of the most high-profile conflicts in Switzerland concerns the extension of the Grimsel hydropower plant: http://www.beobachter.ch/natur/umweltpolitik/ energiepolitik/artikel/grimsel-kraftwerke_ein-tal-unter-strom/.
} 

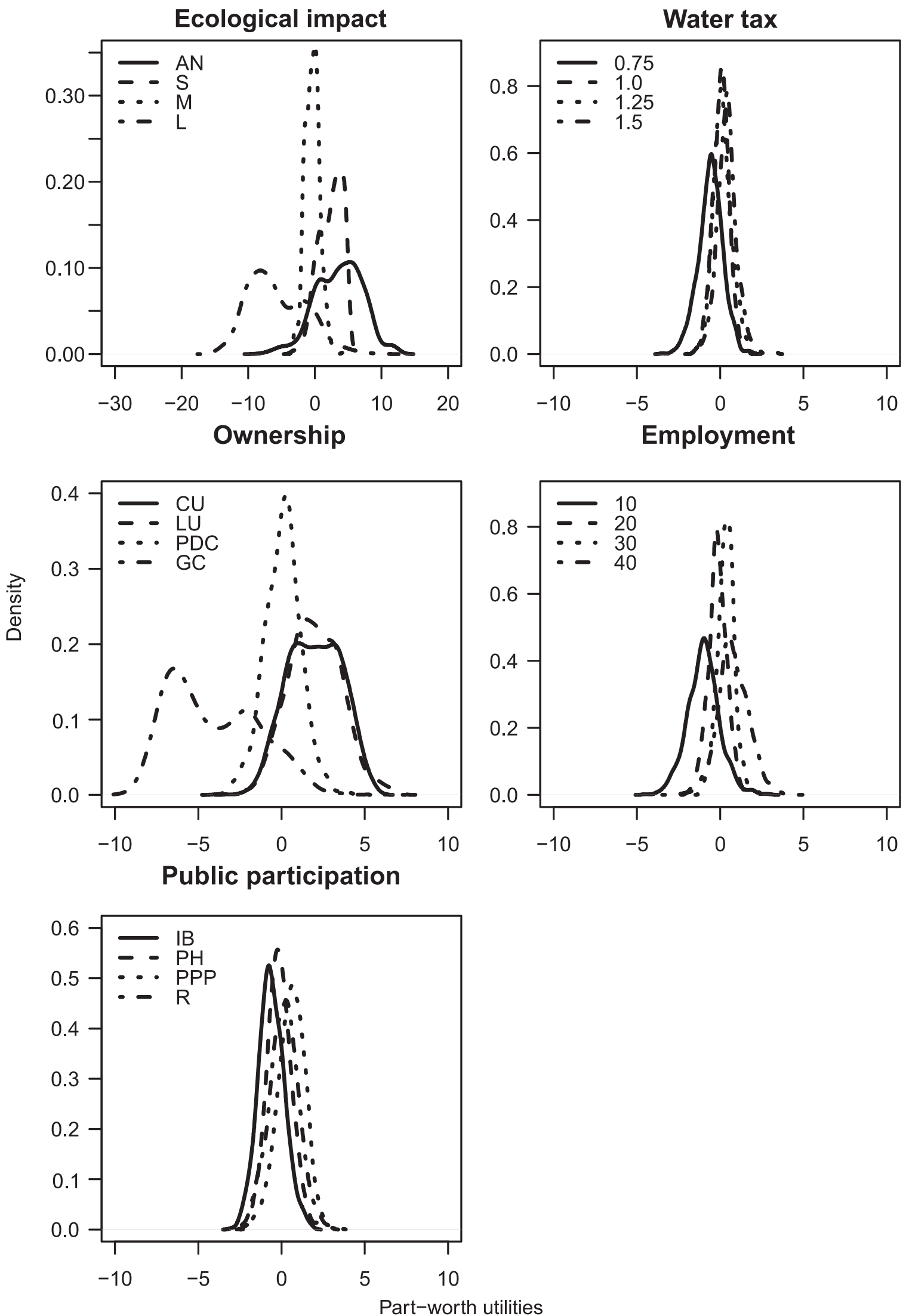

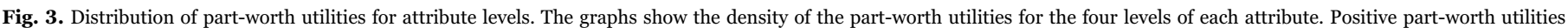

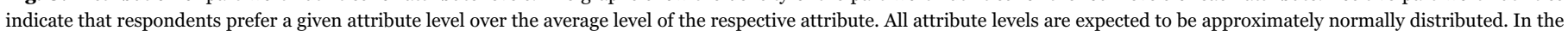
case of ecological impact and ownership, the most and least preferred attribute levels show a slightly asymmetric distribution, reflecting the heterogeneity of preferences. 
as expected: projects that create more jobs are preferred over projects that create fewer jobs. The other element of distributional justice, the water tax, turns out to be the least important attribute (7.55\%). This might be explained by Swiss consumers' comparatively low price sensitivity; an observation which is in line with findings from other surveys of the electricity sector [10]. Another explanation is that revenues from the water tax would not constitute personal income for respondents, as we assumed it would be paid to the municipality or canton. As for procedural justice, respondents appreciate participation, but not as strongly as one might expect. At $9.76 \%$ importance, this attribute had only slightly more explanatory power than the water tax in terms of respondents' acceptance of a hydropower project. One interpretation of this finding is that if a minimum level of participation is assured, more participation may not necessarily lead to greater acceptance. This finding contrasts with the results of some previous research that suggested the existence of a positive linear relationship between participation and acceptance. We would caution, however, that this result has to be seen in the light of the specific institutional environment in which the research was undertaken. Switzerland, with its direct democracy, already offers sufficient legal provision for citizens to have their voice heard.

\subsection{Influence of socio-demographic and psychographic variables}

Among the socio-demographic variables, gender appears to make little difference in terms of how respondents value ecological impact, ownership, and participative planning process (Table 5). Male respondents place more emphasis on the need for distributional justice, i.e. they had a stronger preference for a higher water tax, while female respondents place more emphasis on participation (procedural justice) and the ownership of hydropower plants. Results show that age has a significant influence on all attributes. Younger respondents are more concerned about ecological impacts and employment and less interested in the ownership of hydropower plants. Income had no measurable effect. More highly educated people also tend to be less concerned about local ownership and have a very strong preference for low ecological impacts. The language variable divides the sample geogra- phically; for respondents from the German-speaking part of Switzerland show a higher level of ecological concern and water tax is preferred and participative planning is eschewed compared to the preferences of respondents from French-speaking areas. Not surprisingly, membership in an environmental organization has a substantial influence on the importance of the ecological attribute and of participative planning process. The variable 'climate change acceptance' is included to capture trends, attribution, impact skepticism and conspiratorial thinking. The higher the value of the aggregated climate change variable, the less climate-skeptic people are. Respondents with higher climate change acceptance scores place substantially more emphasis on the need to lower ecological impacts. This indicates that, despite its low-carbon nature, hydropower may only be acceptable to people who care about climate change if other ecological impacts are also well managed.

The 'Worldview' variable shows that respondents with a strong freemarket preference care less about (local) ownership and participation. It increases with attributes representing distributional justice. Political view has also an impact in the model on the two most important attributes. Switzerland's political system is peculiar in that the federal government is composed of all major parties but the largest party, the national-conservative Swiss people's party (SVP), regularly opposes the political consensus and launches popular initiatives that contradict official government positions [18]. To reflect this cleavage, we defined the variable 'political view' as a dummy where 1 indicates that the respondent stated support for SVP, and 0 support for any other party. SVP voters assigned less importance to mitigating ecological impacts, whereas they were more strongly in favor of local ownership.

We were also interested in understanding whether knowledge about the ecological impacts of hydropower or living close to a river has a measurable influence on social acceptance of hydropower. The preexisting knowledge variable was constructed similarly to climate change acceptance, based on six items measured on a Likert-scale (see Appendix B), meaning that the higher the value of this variable, the higher the pre-existing knowledge about the negative consequences of hydropower generation. These variables were found to have no significant impact.

Table 5

Relationship between most preferred attribute levels and other factors. The dependent variables are the rescaled part-worth utilities of the most preferred attribute levels (shown in columns). The most parsimonious models are shown in the table, which were selected based on AIC criterion. Variables that have no estimates were excluded from the analysis (backward selection was performed).

\begin{tabular}{|c|c|c|c|c|c|c|c|c|c|c|}
\hline & \multicolumn{2}{|c|}{$\begin{array}{l}\text { Ecological impact: } \\
\text { 'None' }\end{array}$} & \multicolumn{2}{|c|}{$\begin{array}{l}\text { Ownership: 'Local } \\
\text { utility' }\end{array}$} & \multicolumn{2}{|c|}{$\begin{array}{l}\text { Water tax: '1.5 million } \\
\text { CHF/year' }\end{array}$} & \multicolumn{2}{|c|}{ Employment: '40 jobs' } & \multicolumn{2}{|c|}{$\begin{array}{l}\text { Public participation: } \\
\text { 'Participative planning process' }\end{array}$} \\
\hline & Estimate & p-value & Estimate & $\mathrm{p}$-value & Estimate & $\mathrm{p}$-value & Estimate & p-value & Estimate & $\mathrm{p}$-value \\
\hline (Intercept) & 54.77 & $* * *$ & 53.15 & $* * *$ & 3.54 & $* * *$ & 18.39 & $* * *$ & 16.94 & $* * *$ \\
\hline $\begin{array}{l}\text { Explicit acceptance } \\
\text { of extension }\end{array}$ & -11.66 & $* * *$ & 5.52 & $* * *$ & 1.11 & NS & 1.59 & NS & - & - \\
\hline $\begin{array}{l}\text { Knowledge of } \\
\text { expansion }\end{array}$ & 6.75 & * & - & - & - & - & -2.28 & NS & 2.52 & * \\
\hline Gender & -5.56 & NS & -4.06 & * & 3.61 & $* * *$ & - & - & -2.38 & * \\
\hline Age & -0.71 & $* * *$ & 0.41 & $* * *$ & -0.05 & $*$ & -0.14 & $* * *$ & -0.07 & * \\
\hline Income & 1.27 & NS & - & - & - & - & - & - & - & - \\
\hline Education & 7.51 & $* * *$ & -3.19 & $* * *$ & 0.59 & NS & - & - & - & - \\
\hline German/French & 14.91 & $* * *$ & -4.50 & NS & 4.64 & $* * *$ & - & - & -7.14 & $* * *$ \\
\hline EnvOrg & 14.81 & $* * *$ & -6.10 & $* *$ & - & - & - & - & 3.51 & $* *$ \\
\hline $\begin{array}{l}\text { Climate change } \\
\text { acceptance }\end{array}$ & 4.63 & $* * *$ & -1.01 & $* *$ & - & - & - & - & - & - \\
\hline Worldview & - & - & -1.78 & $* *$ & 1.10 & $* * *$ & 1.06 & $* *$ & -0.72 & * \\
\hline Political view & -13.68 & $* *$ & 10.21 & $* *$ & - & - & -3.62 & NS & -3.99 & $*$ \\
\hline $\begin{array}{l}\text { Pre-existing } \\
\text { knowledge }\end{array}$ & - & - & - & - & - & - & - & - & 0.47 & $* * *$ \\
\hline Direct view & - & - & - & - & - & - & - & - & - & - \\
\hline River use & - & - & - & - & - & - & - & - & - & - \\
\hline $\mathbf{R}^{2}$ & 0.20 & & 0.09 & & 0.05 & & 0.02 & & 0.05 & \\
\hline
\end{tabular}

${ }^{* * *} \mathrm{p}<0.01,{ }^{* *} \mathrm{p}<0.05,{ }^{*} \mathrm{p}<0.1, \mathrm{NS}=$ not significant. 
Finally, we included a question that explicitly asked about respondents' willingness to accept a hydropower project to confirm the validity of the choice experiment. The explicit acceptance measure does indeed have a significant effect on the two most important attributes in the choice experiment, giving us confidence in the design of the choice experiment. Directly measured acceptance and ecological impact are negatively correlated, which implies that concerns about ecological impacts lead to lower levels of acceptance. As could be expected, local ownership is positively related to social acceptance of hydropower.

\subsection{Implicit willingness-to-accept}

To calculate implicit willingness-to-accept (WTA) we used a fixed cost coefficient and estimated the WTA at an individual level, as suggested by Sillano and Ortuzar [53]

First, we estimated the effect of the annual water tax as a linear monetary coefficient based on individual preferences. This was done by dividing the difference between the highest and lowest raw part-worth utilities by the difference between the highest and lowest levels of the attribute. As a result, we can convert the value of utility points into an equivalent monetary value (in Mio. CHF of yearly income for the local community and canton from the water tax.) The most preferred levels for each individual within an attribute are set as defaults and then mean-centered. Respondents' implicit WTA for levels of all nonmonetary attributes relative to the most preferred level of a given attribute was calculated by dividing mean-centered utilities by the monetary coefficient, using the following formula:

$W T A_{i}=\left(\frac{\beta_{i, \max }-\beta_{i j}}{M F_{i}}\right)$

$M F_{i}=\frac{\beta_{i, \max }-\beta_{i, \min }}{p_{\max }-p_{\min }}$

where $\beta_{i j}$ indicates the part-worth utility value of attribute $i$ at level $j$ and $\beta_{i, \max }$ indicates the highest part-worth utility value within attribute $i . M F_{I}$ is the linear monetary factor, which is the ratio of the minimum and maximum values of the part-worth utilities $\left(\beta_{\max }\right.$ and $\left.\beta_{\min }\right)$ to the levels of the monetary attribute $\left(\mathrm{p}_{\max }\right.$ and $\left.\mathrm{p}_{\min }\right)$. In order to facilitate interpretation of the results, the monetary attribute levels are converted into Rp./kWh (which is the standard unit for indicating electricity prices and water tax levels) using the following assumptions regarding the hydropower plant: $10 \mathrm{MW}$ installed capacity, 6000 full load hours (60'000 MWh electricity generation per year).

By means of measuring implicit WTA at an individual level we are able to capture the heterogeneity of preferences. Non-zero mean values in Table 6 reflect the heterogeneity of choices: i.e. not all respondents consider (for example) 'no' ecological impact to be the most preferable level of this attribute. To account for this heterogeneity, we chose median values as a proxy of the population's implicit WTA.

All else being equal, in order to accept a hydropower plant that has medium ecological impacts, respondents think that the canton/community should be compensated by about 3.5 cents per $\mathrm{kW}$ h. Large ecological impacts are essentially a no-go, as indicated by the prohibitively high WTA of 8 cents per kWh compared to a hydropower plant with almost no ecological impacts. As for ownership, moving from a hydropower plant owned by a municipal or cantonal public utility to one that is owned by a private domestic firm, respondents would expect a premium of about 1.7 cents/kW h. Foreign ownership is the least preferred level, as indicated by the almost prohibitively high WTA of 5.4 cents $/ \mathrm{kW}$ h.

While indirectly measuring WTA in a conjoint experiment is preferable in some ways to directly eliciting WTA in terms of overcoming social desirability bias, our results are still based on an experimental setting. Also, our research design assumed that no
Table 6

Implicit willingness to accept attribute levels of hydropower project (Rp./ $\mathrm{kW} \mathrm{h}$ ).

\begin{tabular}{llllll}
\hline Attribute levels & Mean & Median & Std. Error & 95\% CI & \\
\hline Ecological impacts & & & & & \\
Almost none & 0.65 & 0.00 & 0.08 & 0.48 & 0.81 \\
Small & 2.11 & 1.37 & 0.10 & 1.92 & 2.30 \\
Medium & 5.21 & 3.48 & 0.20 & 4.81 & 5.61 \\
Large & 11.06 & 7.90 & 0.39 & 10.28 & 11.83 \\
& & & & & \\
Ownership & & & & & \\
Cantonal utility & 0.61 & 0.16 & 0.03 & 0.54 & 0.67 \\
Local utility & 0.63 & 0.18 & 0.04 & 0.56 & 0.70 \\
Private domestic company & 2.97 & 1.87 & 0.12 & 2.73 & 3.20 \\
German company & 7.79 & 5.44 & 0.27 & 7.27 & 8.32 \\
& & & & & \\
Employment & & & & & \\
10 jobs & 2.09 & 1.60 & 0.06 & 1.96 & 2.22 \\
20 jobs & 1.21 & 0.91 & 0.04 & 1.13 & 1.30 \\
30 jobs & 0.74 & 0.52 & 0.03 & 0.68 & 0.80 \\
40 jobs & 0.34 & 0.00 & 0.03 & 0.29 & 0.39 \\
& & & & & \\
Public participation & & & & & \\
Information brochures & 1.86 & 1.30 & 0.07 & 1.73 & 1.99 \\
Public hearing & 1.27 & 0.88 & 0.05 & 1.17 & 1.37 \\
Participative planning process & 0.51 & 0.00 & 0.03 & 0.44 & 0.58 \\
Referendum & 0.95 & 0.58 & 0.04 & 0.87 & 1.03 \\
\hline & & & & & \\
\hline
\end{tabular}

monetary compensation would personally accrue to respondents, but rather to the community and the canton. While this realistically mirrors the situation with hydropower projects in Switzerland, it may have affected respondents' assessments of the monetary attribute. As a result, the monetary WTA values presented here should be interpreted with care.

\section{Conclusion and discussion}

This paper adds to the stream of research on social acceptance of hydropower through its description and analysis of a choice experiment that was conducted with a representative sample of the Swiss population $(\mathrm{N}=1004)$. The objective was to measure stated preferences about factors that determine social acceptance of hydropower, which is an important source of renewable energy in Switzerland and many other countries, and which the government sees as a key contributor to its energy strategy 2050.

Based on the findings of our empirical analysis, we may now address the key research question outlined at the beginning of the paper: "What is the influence of procedural justice and distributional justice on social acceptance, compared to other attributes of a hydropower project?" Our analysis shows that procedural justice and distributional justice do indeed play a role in determining social acceptance of hydropower. Out of the five attributes of a hydropower project included in our choice experiment, the level of participation (representing procedural justice) and the size of the water tax and the number of jobs created (representing distributional justice) explain between 7 and 11 per cent of respondents' choices. Compared to the prominence awarded to procedural justice and participatory decisionmaking in the social acceptance literature, the relatively low importance of this attribute may come as a surprise. Our findings indeed suggest that greater levels of participation are not a panacea and should remind project developers of the fact that involving local stakeholders is a worthwhile endeavor, but does not come for free. Rather than pursuing the simple goal of maximizing participation and assuming that a project will always go ahead if everyone can be made to amicably sit around the table, the challenge is for project developers to identify salient stakeholders [41] and to understand what it is that they really care about. At the same time, they should remember that, while small, the effect of participation clearly exists - and, as many delayed or cancelled projects suggest, failing to take participatory decision making 
Table 7

Variables used in regression analysis.

\begin{tabular}{|c|c|c|c|}
\hline Variable & Proposition & Mean & $\begin{array}{l}\text { Std. } \\
\text { Dev. }\end{array}$ \\
\hline $\begin{array}{l}\text { Acceptance of } \\
\text { hydropower } \\
\text { project }\end{array}$ & $\begin{array}{l}\text { Are you for or against the expansion of } \\
\text { hydropower in Switzerland? (Likert-scale, } \\
1=\mathrm{I} \text { am against it, } 2=\mathrm{I} \text { am rather against, } \\
3=\mathrm{I} \text { am rather for, } 4=\mathrm{I} \text { am for the } \\
\text { extension) }\end{array}$ & 1.58 & 0.66 \\
\hline $\begin{array}{l}\text { Knowledge of } \\
\text { hydropower } \\
\text { project }\end{array}$ & $\begin{array}{l}\text { Are you aware of a recent project to } \\
\text { expand or construct a hydropower plant in } \\
\text { Switzerland? (dummy, } 1=\text { yes, } 0=\text { no) }\end{array}$ & 0.42 & 0.49 \\
\hline Gender & Dummy, $1=$ male, $0=$ female & 0.48 & 0.5 \\
\hline Age & Continuous & 46.86 & 15.80 \\
\hline Income & Categorical & 5.21 & 2.47 \\
\hline Education & Categorical & 5.49 & 1.32 \\
\hline Language & Dummy, $1=$ German, $0=$ French & 0.77 & 0.42 \\
\hline EnvOrg & $\begin{array}{l}\text { Dummy, } 1=\text { Member in an environmental } \\
\text { organization }\end{array}$ & 0.21 & 0.41 \\
\hline $\begin{array}{l}\text { Climate change } \\
\text { acceptance }\end{array}$ & $\begin{array}{l}\text { Categorical, aggregated (Likert-scale, } \\
\text { 1=agree, } 2=\text { rather agree, } 3=\text { rather } \\
\text { disagree, } 4=\text { disagree) } \\
\text { - I am uncertain whether climate } \\
\text { change is really happening (trend } \\
\text { skepticism) } \\
\text { - Climate change is entirely caused by } \\
\text { natural processes (attribution } \\
\text { skepticism) } \\
\text { - The severity of climate change is } \\
\text { exaggerated (impact skepticism) } \\
\text { - Climate change is an excuse for } \\
\text { patronizing citizens (conspiratorial } \\
\text { thinking) }\end{array}$ & 13.05 & 2.67 \\
\hline Worldview & $\begin{array}{l}\text { Categorical, aggregated (Likert-scale, } \\
1=\text { agree, } 2=\text { rather agree, } 3=\text { rather } \\
\text { disagree, } 4=\text { disagree) } \\
\text { - Free and unregulated markets } \\
\text { threaten the environment } \\
\text { - Unbridled capitalism is leading the } \\
\text { world into disaster }\end{array}$ & 4.03 & 1.49 \\
\hline Political view & $\begin{array}{l}\text { Dummy, } 1=\text { preference for conservative } \\
\text { Swiss people's party SVP, } 0=\text { other }\end{array}$ & 0.10 & 0.30 \\
\hline $\begin{array}{l}\text { Pre-existing } \\
\text { knowledge }\end{array}$ & $\begin{array}{l}\text { Categorical, aggregated (Likert-scale, } \\
1=\text { agree, } 2=\text { rather agree, } 3=\text { rather } \\
\text { disagree, } 4=\text { disagree) }\end{array}$ & 15.98 & 3.87 \\
\hline Direct view & $\begin{array}{l}\text { Dummy, } 1=\text { have direct view to river/ } \\
\text { stream }\end{array}$ & 0.22 & 0.41 \\
\hline River use & $\begin{array}{l}\text { Categorical, (Number of river activities } \\
\text { respondents do, e.g. swimming, fishing, } \\
\text { walking etc.) }\end{array}$ & 1.66 & 1.18 \\
\hline
\end{tabular}

Table 8

Preexisting knowledge about the ecological impacts of hydropower generation (4-point Likert scale).

\begin{tabular}{|c|c|c|c|c|c|}
\hline & Not known & $\begin{array}{l}\text { Rather } \\
\text { not } \\
\text { known }\end{array}$ & $\begin{array}{l}\text { Rather } \\
\text { known }\end{array}$ & Well known & Total \\
\hline Hydropeaking & $22.51 \%$ & $20.02 \%$ & $38.45 \%$ & $19.02 \%$ & $100 \%$ \\
\hline $\begin{array}{l}\text { Impairment of the } \\
\text { fish population }\end{array}$ & $6.27 \%$ & $12.05 \%$ & $44.32 \%$ & $37.35 \%$ & $100 \%$ \\
\hline $\begin{array}{l}\text { Erosion and impacts } \\
\text { on riparian } \\
\text { vegetation }\end{array}$ & $10.36 \%$ & $23.21 \%$ & $45.52 \%$ & $20.92 \%$ & $100 \%$ \\
\hline $\begin{array}{l}\text { Impairment of } \\
\text { zoobenthos }\end{array}$ & $20.32 \%$ & $30.98 \%$ & $34.96 \%$ & $13.75 \%$ & $100 \%$ \\
\hline Landscape change & $5.78 \%$ & $12.95 \%$ & $44.92 \%$ & $36.35 \%$ & $100 \%$ \\
\hline Chemical exposure & $35.76 \%$ & $36.06 \%$ & $19.72 \%$ & $8.47 \%$ & $100 \%$ \\
\hline
\end{tabular}

into account can be costly.

Beyond procedural and distributional justice, however, the research findings suggest that two attributes play a much larger role in determining social acceptance, namely ecological impacts and local ownership. Taken together, these two attributes explain more than $70 \%$ of respondents' choices to accept a hydropower project or not. Above all, our findings for Switzerland confirm the outcomes of Klinglmair et al.'s [25] study $^{5}$ in Austria, and Kataria's [23] survey of Swedish households: the ecological impact of hydropower is something that people (at least in the aforementioned countries) are genuinely concerned about. Accordingly, the government would be well advised to continue to strike a careful balance between energy and environmental policy objectives.

The other important message that arises from our analysis is that who the owner is matters. The Swiss residents we surveyed report that whether a hydropower plant is owned by a local or cantonal utility, a private domestic company or a foreign investor is important to them with preferences decreasing in that order. In particular, foreign ownership of a hydropower plant (operationalized as a German company in our experiment) is almost a no-go. The identification of such preferences for local ownership are in line with previous findings from the renewable energy literature $([39,61,8,58)]$, and could possibly be interpreted as indirect confirmation of the importance of distributional justice. While local ownership does not guarantee that more wealth will actually be created and equitably shared in a community, it could be the case that respondents make this assumption implicitly, assuming that foreign investors are more likely to 'take the money and run' than locally-embedded organizations.

In summary, our findings show that while consideration of procedural and distributional justice is necessary, it is not sufficient to ensure social acceptance. Above all, our research indicates that successfully addressing people's concerns about potential ecological impact and ownership (i.e. keeping a hydropower project "local and fish-friendly") are the most important determinants of social acceptance.

Our research additionally identified the impacts of some sociodemographic and psychographic variables on social acceptance of hydropower. A preference for minimizing ecological impacts correlates with strong belief in climate science, supporting the findings of Lewandowsky et al. [30]. This suggests that ecological interests and climate concerns are coupled, and rather than trading off one against the other, the respondents prefer low-carbon energy sources to be deployed in an environmentally responsible way.

Furthermore, membership of an environmental organization, belief in climate science, sympathizing less with national-conservative political views, being younger or being more highly educated than the sample average increase the likelihood that a respondent will emphasize the need to reduce ecological impact. These findings are in line with previous studies using choice experiments including ecological impacts [1,7]. Respondents who are not fitting the above demographic profile are more concerned about who the owners of the hydropower plant will be. Being older than the sample average and having conservative political views has a positive, while income, education and environmental organizational membership has a negative relationship to the importance of local ownership.

Furthermore, familiarity (direct view, river use, pre-existing knowledge) with the subject has almost no measurable effect on preferences. It appears that psychographic factors such as membership in an environmental organizations or political views shape public opinions about hydropower more than physical proximity.

\footnotetext{
5 [25] found a willingness-to-accept for strong versus small impact on nature and landscape of 13.51 Euros per month. While there are methodological differences between the two studies, the results are pointing in similar directions. If we substract the corresponding median WTA for large $(7.90 \mathrm{ct} / \mathrm{kWh})$ versus small $(1.37 \mathrm{ct} / \mathrm{kWh})$ ecological impacts in our study, convert the values to Euros and assume an average residential electricity consumption of $2500 \mathrm{kWh}$ per capita and year, we come to a WTA of 12.37 Euros per month.
} 


\section{Limitations and further research}

Our study makes a number of important contributions to the literature on social acceptance of renewable energy. First, despite the importance of hydropower in the global energy transition, there is a scarcity of research on this topic. Our large-scale survey on the social acceptance of hydropower contributes important empirical insights to the debate. Secondly, prior research in this domain has often taken either a qualitative case study approach or looked at ecological impacts in isolation, mostly using contingent valuation studies. By including the most important dimensions of social acceptance of hydropower into a realistic choice experiment, we were able to quantify the relative importance of various attributes of a hydropower project with regard to respondents' decisions to accept or reject such projects. Finally, this study is one of the first to shed light on the relative influence of procedural justice and distributional justice on social acceptance and puts them into perspective alongside other project attributes such as ecological impacts and local ownership.

As with any piece of empirical research, our study is subject to limitations that highlight opportunities for further work. Firstly, the research was conducted in a single country with a long tradition of hydropower use, Switzerland. While we indicated in the discussion that several of our findings confirm research findings from culturallysimilar settings (such as Austria and Sweden), the institutional environment in which this research took place needs to be taken into consideration before drawing conclusions about its relevance to other countries. For example, the relatively low influence of procedural and distributional justice might reflect the fact that Swiss legislation clearly defines the right to participation during the planning of hydropower plants, as well as standards regarding the compensation of local communities through a water tax. Respondents in our sample may have taken these elements of environmental justice for granted, allowing them to emphasize the importance of other attributes (such as ecological impacts). Procedural and distributional justice may be valued differently in countries with a less participatory culture and different institutional environments.

A second limitation of the research is that (local) ownership was found to be the second most important attribute in explaining social acceptance. While this result is in line with the recent rise in local renewable energy initiatives that have occurred in many countries and may thus reflect a broader trend in the energy sector, an alternative explanation is that the way we operationalized the attribute evoked specific associations for some respondents. The correlation that was identified between political orientation and aversion to foreign ownership suggests that useful research could be undertaken to identify whether the importance of local ownership remains high even in the absence of a project developer with an explicitly specified foreign nationality.

Finally, we operationalized the monetary attribute in the form of annual tax income that would benefit both community and canton. This mirrors the reality of hydropower projects in Switzerland, but lessens the direct relevance of the financial impacts of the choice situation to individual respondents. We encourage further research that explores alternative operationalizations of distributional justice, including options that would offer respondents direct personal benefits.

\section{Acknowledgements}

The authors wish to acknowledge financial support from the Commission for Technology and Innovation (CTI) under the Swiss Competence Centers for Energy Research (SCCER CREST), as well as helpful comments from two anonymous reviewers. Any remaining errors are our own.

\section{Appendix A}

See Table 7.

\section{Appendix B}

See Table 8.

\section{References}

[1] Agimass F, Mekonnen A. Low-income fishermen's willingness-to-pay for fisheries and watershed management: an application of choice experiment to Lake Tana, Ethiopia. Ecol Econ 2011;71:162-70.

[2] G.M. Allenby, P.E. Rossi, R.E. McCulloch. Hierarchical Bayes Models: A Practitioners Guide, SSRN working paper; 2005.

[3] Arabatzis G, Myronidis D. Contribution of SHP Stations to the development of an area and their social acceptance. Renew Sustain Energy Rev 2011;15(8):3909-17.

[4] Aravena C, Hutchinson WG, Longo A. Environmental pricing of externalities from different sources of electricity generation in Chile. Energy Econ 2012;34(4):1214-25.

[5] BFE . Schweizerische Elektrizitätsstatistik 2014. Bern: Bundesamt für Energie; 2015.

[6] BfS. (Bundesamt für Statistik), 〈http://www.bfs.admin.ch/bfs/portal/de/index/ themen/01/05/blank/key/religionen.html ; 2014

[7] Birol E, Karousakis Katia, Koundouri Phoebe. Using a choice experiment to account for preference heterogeneity in wetland attributes: the case of Cheimaditida wetland in Greece. Ecol Econ 2006;60(1):145-56.

[8] Boon FP, Dieperink C. Local civil society based renewable energy organisations in the Netherlands: exploring the factors that stimulate their emergence and development. Energy Policy 2014;69:297-307.

[9] Bruder A, Vollenweider S, Schweizer S, Tonolla D, Meile T. Schwall und Sunk: auswirkungen auf die Gewässerökologie und mögliche Sanierungsmassnahmen. Wasser-Energ-Luft 2012;104(4):257-64.

[10] Burkhalter A, Kaenzig J, Wüstenhagen R. Kundenpräferenzen für leistungsrelevante Attribute von Stromprodukten. Z für Energ 2009;33(2):161-72.

[11] Caporale D, De Lucia C. Social acceptance of on-shore wind energy in Apulia Region (Southern Italy). Renew Sustain Energy Rev 2015;52:1378-90.

[12] Carson RT, Flores NE, Meade NF. Contingent valuation: controversies and evidence. Environ Resour Econ 2001;19(2):173-210.

[13] Ewing G, Sarigöllü E. Assessing consumer preferences for clean-fuel vehicles: a discrete choice experiment. J Public Policy Mark 2000;19(1):106-18.

[14] Gampfer R, Bernauer T, Kachi A. Obtaining public support for North-South climate funding: evidence from conjoint experiments in donor countries. Glob Environ Change 2014:29:118-26.

[15] Gowan C, Stephenson K, Shabman L. The role of ecosystem valuation in environmental decision making: hydropower relicensing and dam removal on the Elwha River. Ecol Econ 2006;56(4):508-23.

[16] Gross C. Community perspectives of wind energy in Australia: the application of a justice and community fairness framework to increase social acceptance. Energy Policy 2007;35(5):2727-36.

[17] Hanley N, Wright RE, Alvarez-Farizo B. Estimating the economic value of improvements in river ecology using choice experiments: an application to the water framework directive. J Environ Manag 2006;78(2006):183-93.

[18] M. Herrmann, I. Städler, Wie sich die SVP aus dem Bürgerblock verabschiedet hat, Tages-Anzeiger, 21, 4, 2014, 〈http://blog.tagesanzeiger.ch/datenblog/index.php/ 1791/wie-sich-die-svp-aus-dem-buergerblock-verabschiedet-hat $\rangle ; 2014$.

[19] Clarvis Hill, Simone Fatichi M, Allan Andrew, Fuhrer Jürg, Stoffel Markus, Romerio Franco, Gaudard Ludovic, Burlando Paolo, Beniston Martin, Xoplaki Elena, Toreti Andrea. Governing and managing water resources under changing hydro-climatic contexts: the case of the upper Rhone basin. Environ Sci Policy 2014;43:56-67.

[20] Huijts NMA, Molin EJE, Steg L. Psychological factors influencing sustainable energy technology acceptance: a review-based comprehensive framework. Renew Sustain Energy Rev 2012;16(1):525-31.

[21] Höffken JI. A closer look at small hydropower projects in India: Social acceptability of two storage-based projects in Karnataka. Renewable and Sustainable Energy Reviews 2014;34:155-66.

[22] Johansson-Stenman O, Konow J. Fair air: distributive justice and environmental economics. Environ Resour Econ 2010;46(2):147-66.

[23] Kataria M. Willingness to pay for environmental improvements in hydropower regulated rivers. Energy Econ 2009;31(1):69-76.

[24] Kaufmann S, Kuenzel K, Loock M. Customer value of smart metering: explorative evidence from a choice-based conjoint study in Switzerland. Energy Policy 2013;53:229-39.

[25] Klinglmair A, Bliem MG, Brouwer R. Exploring the public value of increased hydropower use: a choice experiment study for Austria. J Environ Econ Policy 2015:1-23.

[26] Kumar D, Katoch SS. Harnessing 'water tower' into 'power tower': a small hydropower development study from an Indian prefecture in western Himalayas. Renew Sustain Energy Rev 2014;39:87-101.

[27] Kumar D, Katoch SS. Small hydropower development in western Himalayas: strategy for faster implementation. Renew Energy 2015;77:571-8.

[28] Kumar D, Katoch SS. Sustainability suspense of small hydropower projects: a study 
from western Himalayan region of India. Renew Energy 2015;76:220-33.

[29] Lehr U, Nitsch J, Kratzat M, Lutz C, Edler D. Renewable energy and employment in Germany. Energy Policy 2008;36(1):108-17.

[30] Lewandowsky S, Oberauer K, Gilles E, Gignac . NASA faked the moon landingTherefore, (Climate) science is a hoax: an anatomy of the motivated rejection of science. Psychol Sci 2013;24(5):622-33.

[31] Lind EA, Tyler TR. The social psychology of procedural justice. New York and London: Plenum Press; 1988.

[32] Loring JM. Wind energy planning in England, Wales and Denmark: factors influencing project success. Energy Policy 2007;35(4):2648-60.

[33] Louviere JJ, Flynn TN, Carson RT. Discrete choice experiments are not conjoint analysis. J Choice Model 2010;3(3):57-72.

[34] Luchsinger C. Abschöpfung der Ressourcenrente in der Schweizer Wasserkraftproduktion [Doctoral dissertation Nr. 16409]. Zurich: Swiss Federal Institute of Technology; 2006.

[35] Luz F. Participatory landscape ecology-a basis for acceptance and implementation. Landsc Urban Plan 2000;50(1):157-66.

[36] Lüthi S, Wüstenhagen R. The price of policy risk-Empirical insights from choice experiments with European photovoltaic project developers. Energy Economics 2012;34(4):1001-11.

[37] Malesios C, Arabatzis G. Small hydropower stations in Greece: the local people's attitudes in a mountainous prefecture. Renew Sustain Energy Rev 2010;14(9):2492-510.

[38] Manaster K. Environmental Protection and Justice: readings and Commentary on Environmental Law and Practice. Cincinnati: Anderson Publishing Co; 1995.

[39] Maruyama Y, Nishikido M, Iida T. The rise of community wind power in Japan: enhanced acceptance through social innovation. Energy Policy 2007;35(5):2761-9.

[40] Meyer K. Akzeptanz von Windenergieprojekten in der Schweiz: die Beurteilung der Gerechtigkeit durch die lokale Bevölkerung [M.A. Thesis]. University of St. Gallen; 2016.

[41] Mitchell R, Agle B, Wood D. Toward a theory of stakeholder identification and salience: defining the principles of who and what really counts. Academy of Management. Acad Manag Rev 1997;22(4):853-86.

[42] Montesinos M. It may be silly, but it's an answer: the need to accept contingent valuation methodology in natural resource damage assessments. Ecol Law Q 1999;26:48-79.

[43] Morrell ME. Citizen's evaluations of participatory democratic procedures: normative theory meets empirical science. Political Res Q 1999;52(2):293-322.

[44] Nadaï A. "Planning", "siting" and the local acceptance of wind power: some lessons from the French case. Energy Policy 2007;35(5):2715-26.

[45] O'Faircheallaigh C. Public participation and environmental impact assessment: purposes, implications, and lessons for public policy making. Environ Impact Assess Rev 2010;30(1):19-27.

[46] Pedersen E, van den Berg F, Bakker R, Bouma J. Response to noise from modern wind farms in The Netherlands. J Acoust Soc Am 2009;126(2):634-43.

[47] R Core Team. R: A language and environment for statistical computing. R Foundation for Statistical Computing, Vienna, Austria. URL: 〈https://www.Rproject.org/>; 2015.

[48] Sammer K, Wüstenhagen R. The influence of eco-labelling on consumer behaviourResults of a discrete choice analysis for washing machines. Business Strategy and the Environment 2006;15(3):185-99.

[49] Sawtooth. Technical Paper Series: The CBC System for Choice-Based Conjoint Analysis; 2013.
[50] SFSO. (Swiss Federal Statistical Office). 〈http://www.bfs.admin.ch/bfs/portal/en/ index/infothek/onlinedb/stattab.html); 2014.

[51] Sharma AK, Thakur NS. Resource potential and development of small hydro power projects in Jammu and Kashmir in the western Himalayan region: India. Renew Sustain Energy Rev 2015;52:1354-68.

[52] Sharma RH, Awal R. Hydropower development in Nepal. Renew Sustain Energy Rev 2013;21:684-93.

[53] Sillano M, Ortuzar J. Willingness-to-pay estimation with mixed logit models: some new evidence. Environ Plan A 2005 2005;37:525-50.

[54] Skitka LJ, Winquist J, Hutchinson S. Are outcome fairness and outcome favorability distinguishable psychological constructs? A meta-analytic review. Soc Justice Res 2003;16:309-41.

[55] Sternberg R. Hydropower's future, the environment, and global electricity systems. Renew Sustain Energy Rev 2010;14(2):713-23.

[56] Stigka EK, Paravantis JA, Mihalakakou GK. Social acceptance of renewable energy sources: a review of contingent valuation applications. Renew Sustain Energy Rev 2014;32:100-6.

[57] Thibaut JW, Walker L. Procedural justice: A psychological analysis. Hillsdale NJ: Lawrence Erlbaum Associates; 1975.

[58] Tabi A, Hille SL, Wüstenhagen R. What makes people seal the green power deal?Customer segmentation based on choice experiment in Germany 2014;107:206-15.

[59] van Rijnsoever F, van Mossel A, Broecks KPF. Public acceptance of energy technologies: the effects of labeling, time, and heterogeneity in a discrete choice experiment. Renew Sustain Energy Rev 2015;45:817-29.

[60] Vande Walle JM. In the eye of the beholder: issues of distributive and corrective justice in the ADA's employment protection for persons regarded as disabled. Chi -Kent L Rev 1997;73:897.

[61] Volz R. Bedeutung und Potenziale von Energiegenossenschaften in Deutschland eine empirische Aufbereitung. Informationen zur Raumentwicklung 2012;9(10):515-24.

[62] Walter G, Gutscher H. Public acceptance of wind energy and bioenergy projects in the framework of distributive and procedural justice theories: insights from Germany, Austria and Switzerland. Zürich: The Advisory House/Universität Zürich; 2010.

[63] Wang G, Fang Q, Zhang L, Chen W, Chen Z, Hong H. Valuing the effects of hydropower development on watershed ecosystem services: case studies in the Jiulong River Watershed, Fujian Province, China. Estuar, Coast Shelf Sci 2010;86(3):363-8.

[64] Woolsey S, Weber C, Gonser T, Hoehn E, Hostmann M, Junker B, Roulier C, Schweizer S, Tiegs S, Tockner K, Peter A. Handbook for evaluating rehabilitation projects in rivers and streams. Publication by the Rhone-Thur project. Eawag: WSL, LCH-EPFL, VAW-ETHZ; 2005.

[65] Wuebker R, Hampl N, Wüstenhagen R. The strength of strong ties in an emerging industry: experimental evidence of the effects of status hierarchies and personal ties in venture capitalist decision making. Strateg Entrep J 2015;9(2):167-87.

[66] Wüstenhagen R, Wolsink M, Bürer MJ. Social acceptance of renewable energy innovation: an introduction to the concept. Energy Policy 2007;35(2007):2683-91.

[67] Ximei L, Ming Z, Xu H, Lilin P, JunRong D. Small hydropower financing in China: external environment analyses, financing modes and problems with solutions. Renew Sustain Energy Rev 2015;48:813-24.

[68] Zacharakis AL, Meyer GD. A lack of insight: do venture capitalists really understand their own decision process?. J Bus Ventur 1998;13(1):57-76. 